\title{
WYPOSAŻENIE LITURGICZNE KOŚCIOLA KLASZTORNEGO W KRAŚNIKU W ŚWIETLE STAROPOLSKICH AKT KRAKOWSKICH WIZYTACJI BISKUPICH
}

Każdy kościół, aby można było w nim właściwie wypełniać funkcje liturgiczne odprawiając Mszę świętą i sprawując inne sakramenty oraz nabożeństwa, powinien posiadać odpowiednie wyposażenie - szaty i naczynia liturgiczne oraz inne konieczne utensylia kościelne. Nie ulega więc najmniejszej wątpliwości, iż takie posiadał także kościół pw. Wniebowzięcia Najświętszej Maryi Panny i św. Augustyna w Kraśniku - w ,szlachetnej prostocie okazały” - wzniesiony przez hojnych fundatorów przy końcu epoki średniowiecza ${ }^{1}$. Po kilku stuleciach, w XIX wieku anonimowy duchowny napisał: „kościół kraśnicki jest bez wątpienia jednym z owych dzieł wytrwałości, które już rozliczne przetrzymało zmiany i długo jeszcze przyszłym opierać się będzie”, pomimo że był on „kilkakroć okradziony [...] i tym sposobem utracił wiele pamiątek, kosztownych kielichów, monstrancji, wotów [...], których pomimo najpilniejszych starań i poszukiwań wynaleźć i odzyskać nie można"’2.

\section{Wstęp}

Podstawę źródłową niniejszej pracy stanowią protokoły powizytacyjne diecezji krakowskiej począwszy od biskupa Jerzego Radziwiłła h. Trąby z lat 1592

* Ks. Andrzej Bruździński - dr hab. historii; prof. w Katedrze Historii Nowożytnej, Wydział Historii i Dziedzictwa Kulturowego Papieskiego Uniwersytetu Jana Pawła II w Krakowie; e-mail: andrzej.bruzdzinski@upjp2.edu.p1

${ }^{1}$ F. M. Sobieszczański, Wiadomości historyczne o sztukach pięknych $w$ dawnej Polsce zawierające opis dziejów i zabytków budownictwa, rzeźby, snycerstwa, malarstwa i rytownictwa, z krótka wzmianka o życiu i dziełach znakomitszych artystów krajowych, lub $w$ Polsce zamieszkałych, t. 1, Warszawa 1847, s. 119.

${ }^{2}$ T. T., Niektóre wiadomości o mieście okręgowem Kraśniku z rękopisu [...], „Biblioteka Warszawska", 27 (1847) t. 3, s. 26; Katalog zabytków sztuki w Polsce, t. 8: Województwo lubelskie, red. R Brykowski, E. Smulikowska, Z. Winiarz, z. 9: Powiat kraśnicki, oprac. J. Galicka, E. Smulikowska, Warszawa 1961, s. 11-21. 
i 1598, poprzez biskupów: Marcina Szyszkowskiego h. Ostoja (1554-1630) z roku 1617, Jakuba Zadzika h. Korab (1582-1642) z roku 1637, Jana Małachowskiego h. Nałęcz (1623-1699) z roku 1689, Kazimierza Łubieńskiego h. Pomian (16521719) z roku 1718 aż do biskupa Kajetana Ignacego Sołtyka h. Sołtyk (17151788) z roku 1781. Najstarsze świadectwa przedstawiające wyposażenie kościoła kraśnickiego rozpoczynają się w czasach, kiedy starano się poprzez wizytacje wprowadzić w życie reformę Kościoła zaprogramowaną na Soborze Trydenckim. Wizytacje były i są do dziś jednym z bardziej podstawowych działań władzy biskupiej w diecezji, za pomocą których może ona wpływać na zmianę życia tak duchownych, jak i powierzonych ich pieczy wiernych. Biskupi - realizując wyznaczony przez Sobór Trydencki cel ,wprowadzenie zdrowej i czystej nauki katolickiej, wypędzenie herezji, zachowanie dobrych obyczajów a poprawa złych, zachęcenie i umocnienie ludu w pobożności przez namowy i upomnienia, utwierdzenie w pokoju i prawości, a także wydanie innych owoców wśród wiernych, stosownie do miejsca, czasu i możliwości, wedle roztropności wizytatorów"3 określali zakres spraw, które miały być przedmiotem wizytacji, a były nim oprócz osób i miejsc także rzeczy. Rzeczy, to znaczy to wszystko, co związane było z kultem Bożym, co jemu służyło i to, co do kościoła należało. Sobór widział w tych rzeczach środki do podniesienia wspaniałości Bożej Ofiary i lepszego rozważania ukrytych tam tajemnic: „światła, okadzenia, szaty i różne inne podobne rzeczy z nauki i tradycji apostolskiej [...] podkreślały majestat tak wielkiej ofiary"4. Sam zaś Kraśnik przeżywał w okresie pierwszych wizytacji czas względnego spokoju i rozwoju, w szczególny sposób rozwoju rzemiosła 5 .

\section{Oltarze i ich wyposażenie}

W roku 1617, za czasów biskupa Marcina Szyszkowskiego, wizytacji dekanatu zawichojskiego, do którego wówczas należał Kraśnik, dokonał kanonik poznański ks. Jakub Piasecki h. Janina († po 1636), prepozytem kraśnickim był wówczas ks. Wojciech Tarnowski. Wizytator stwierdził, że w Kraśniku główny ołtarz jest kamienny, konsekrowany i położony na trzech stopniach. Znajdowały się na nim dwie pary mosiężnych lichtarzy. W retabulum znajdowała się figura (sculpta) Koronacji Wniebowziętej Matki Bożej, można domyślać się, iż była to Matka Boża Apokaliptyczna 6 .

W czasie drugiej wizytacji kanonicznej za rządów kard. Jerzego Radziwiłła w roku 1598, gdy miejscowym prepozytem był Marcin Nawojski z Mielca, stwier-

${ }^{3}$ Sobór Trydencki, Sesja 24, Dekret o reformie 3: Patriarchae, primates, w: Dokumenty Soborów Powszechnych, oprac. A. Baron, H. Pietras, t. 4, Kraków 2004 (dalej: DSP), s. 739.

${ }^{4}$ Sobór Trydencki, sesja 22, rozdz. 5: Cumque natura hominium, kan. 7, DSP, s. 643, 647; A. Nowowiejski, Paramenta, w: Encyklopedja kościelna podtug teologicznej encyklopedii Wetzera i Weltego, z licznemi jej dopetnieniami, t. 18, Warszawa 1892, s. 244.

${ }^{5}$ W. Szymanek, Z dziejów powiatu janowskiego i kraśnickiego w latach 1474-1975, Lublin 2003, s. 13-14.

${ }^{6}$ Archiwum Kurii Metropolitalnej w Krakowie (dalej AKMK), rkps AVCap 34, Acta vistationum exteriorum archidiaconatus Zawichosten[si] opera commissaria Rndi D. Jacobi Piasecki decani Kielcen[si], canonici Posnanensi in anno Dni [1617] diebus iunii et iulli confectae, k. 12v. 
dził, że sacrarium (ciborium) ścienne jest dobrze zamknięte 7 . Znajdowało się ono naprzeciw chrzcielnicy, co było częstym w Polsce zjawiskiem ${ }^{8}$. W roku 1617 odnotowano istnienie tabernakulum umieszczonego w głównym ołtarzu ${ }^{9}$. Nakaz ustawienia tabernakulum w ołtarzu głównym i umieszczenia przed nim wiecznej lampki wprowadził w diecezji krakowskiej biskup Bernard Maciejowski h. Ciołek (1548-1608) listem pasterskim z roku 1601 poświęconym najbardziej palącym $\mathrm{i}$ istotnym problemom duszpasterskim danego czasu, nie tylko w diecezji, ale całej Rzeczypospolitej. Nakaz ustawienia tabernakulum w głównym ołtarzu został wzmocniony wskazaniami zawartymi w Ceremoniale episcoporum papieża Klemensa VIII (1592-1605) z 1604 roku i w Rituale Romanum z roku 1614 papieża Pawła V (1605-1621) ${ }^{10}$. Brak jednak było w Kraśniku przed tabernakulum wiecznej lampki. Pozostałe wizytacje na ten temat już milczą, co oznacza, że wszystko wtedy było zgodne z zaleceniami Kościoła. Sytuacja z tabernakulum w Kraśniku była więc typowa dla ówczesnej polskiej rzeczywistości ${ }^{11}$.

W roku 1617 w tymże kościele było jeszcze pięć ołtarzy bocznych, z których dwa, także kamienne, położone na dwóch stopniach znajdowały się blisko ołtarza głównego, jeden po stronie Ewangelii, drugi Epistoły. Na każdym z nich znajdowały się dwa drewniane świeczniki. W jednym z nich ad cornu Evangelii znajdował się obraz Zbawiciela a w drugim a cornu Epistolae Matki Bożej - zapewne świadczyły one o ich patrocinium. Kolejny ołtarz, również posiadający dwa stopnie, nosił wezwanie Trójcy Świętej i był on wówczas nowy, ale już konsekrowany W pozłoconym retabulum umieszczony był obraz Świętej Trójcy, na ołtarzu znajdowały się dwa mosiężne lichtarze. Następny ołtarz, noszący wezwanie św. Anny, posiadał w retabulum obraz patronki, także był konsekrowany. Prowadziły do niego dwa stopnie. Na ołtarzu znajdowały się dwa mosiężne lichtarze. Ostatni ołtarz nosił wezwanie św. Jana Jałmużnika, wzniesiony na dwóch stopniach. Znajdowały się na nim dwa lichtarze, ale tym razem drewniane. W retabulum znajdował się stary krzyż. W kaplicy brackiej bractwa różańcowego był z kolei ołtarz, w którego retabulum znajdował się obraz Matki Bożej. Prowadziły do niego trzy stopnie, na nim zaś stały dwa mosiężne lichtarze ${ }^{12}$. s. 11.

${ }^{7}$ AKMK, rkps AVCap 12, Visitatio Ecclesiarum in Archidiaconatu Zavichostensi anno D. 1598,

${ }^{8}$ J. A. Czajkowski, Opis kościoła parafialnego w Kraśniku i wiadomość historyczna o kanonikach regularnych lateraneńskich, „Pamiętnik Religijno-Moralny”, 8 (1845) z. 1, s. 34-49; A. Rafałko, Dzieje tabernakulum w Polsce, w: Studia z dziejów liturgii w Polsce, red. W. Schenk, t. 4, Lublin 1984, s. 212-217.

${ }^{9}$ AKMK, rkps AVCap 34, k. 12.

${ }^{10}$ S. Nasiorowski, „List Pasterski” kard. Bernarda Maciejowskiego, Lublin 1992, s. 238; E. Korpysz, Zmiany w sposobie przechowywania Eucharystii w świetle działalności bp. Mattea Gibertiego oraz potrydenckich reform św. Karola Boromeusza i późniejszych synodów, w: Studia de Arte Moderna, t. 1: Sztuka po Trydencie, red. K. Kuczmana, A. Witko, Kraków 2014, s. 47-53; H. Weryński, Tabernakulum. Szkic historyczno-liturgiczny, Miejsce Piastowe 1932², s. 14-15; Rafałko, Dzieje tabernakulum w Polsce, s. 224-227.

${ }^{11}$ E. Wiśniowski, Kościół parafialny i jego funkcje społeczne w średniowiecznej Polsce, „Studia Theologica Varsaviensa", 7 (1969) nr 2, s. 216.

${ }^{12}$ AKMK, rkps AVCap 34, k. 12v-13. 
W czasie wizytacji w roku 1689, gdy prepozytem kanoników był Herkulan Kaczorowicz ( $†$ 1704), wszystkich ołtarzy w kraśnickim kościele było już jedenaście, w tym trzy były nowe, wszystkie były konsekrowane i posiadały mensy kamienne. Nie wyliczając wszystkich patrociniów ołtarzy w sprawozdaniu powizytacyjnym wspomniano jedynie o ołtarzach Przemienienia Pańskiego i św. Marii Magdaleny ${ }^{13}$. W 1718 roku, gdy wizytował Kraśnik ks. Mikołaj Złotnicki, w kościele było trzynaście ołtarzy ${ }^{14}$. Wizytacja dziekana pilickiego, ks. Antoniego Franciszka Dunina Kozickiego h. Łabędź († 1794), z 30 grudnia 1781 roku, za czsów biskupa Sołtyka, odbyta pod nieobecność proboszcza, ks. Józefa Wilhelma Chwasteckiego († 1808), podaje wszystkie wezwania ołtarzy bocznych: Najświętszego Salvatora i Matki Bożej przy głównym ołtarzu. Czwarty w kaplicy Matki Bożej Różańcowej, piąty Pana Jezusa Ukrzyżowanego w kaplicy, szósty św. Anny przy filarze po stronie Ewangelii, siódmy św. Marii Magdaleny po przeciwnej stronie, ósmy św. Antoniego Padewskiego po stronie Ewangelii, dziewiąty św. Józefa po stronie Epistoły, dziesiąty św. Mikołaja po stronie Ewangelii, jedenasty św. Michała. W kaplicy po stronie Ewangelii św. Tekli a z drugiej kaplicy po stronie przeciwnej Przemienienia Pańskiego ${ }^{15}$. Ilość ołtarzy w kościele kraśnickim uzależniona była przede wszystkim od ilości kapłanów tam mieszkających, ale także od beneficjów i fundacji z nimi związanych, choć nie można wykluczyć czynnika wynikającego z pewnego rodzaju „mody”16. Wszystkie ołtarze były konsekrowane, jednakże w czasie ostatniej krakowskiej wizytacji w 1781 roku nie znano dat tych wydarzeń gdyż „pogorzelisko kościoła i klasztoru autentyki zniszczyło". Podano jedynie, iż 12 listopada 1762 roku biskup bakowski Stanisław Rajmund Jezierski h. Nowina (1697-1782) konsekrował ołtarze: Ukrzyżowanego, Matki Bożej, św. Marii Magdaleny oraz św. Michała ${ }^{17}$. Kościół posiadał wówczas pięćdziesiąt lichtarzy cynowych i cztery pary mosiężnych ${ }^{18}$. Podczas pierwszej wizytacji Radziwiłłowskiej odbytej 19 czerwca 1592 roku, gdy przełożonym klasztoru był ks. Andrzej Zagórski, odnotowano sześć antepediów, z których trzy

${ }^{13}$ AKMK, rkps AVCap 55, Visitatio externa archidiaconatus Zawichostensis a. D. 1689 in mense Novembre et Decembre expedita, in qua iura ecclesiarum proventus parochorum una cum descriptionibus ecclesiarum et aedificiorum, noviter et ante existentium, connotata demonastrantur. Decanatus: Urzędowiensis, Zawichostensis et Opatoviensis, s. 48.

${ }^{14}$ AKMK, rkps AVCap 58, Visitatio interna et externa archidiaconatus Zawichostensis, tres: Urzędoviensem, Zawichostensem, Opatoviensem decanatus in se continentis per R. D. Nicolaum a Złotniki Złotnicki, Leopoliensem canonicum, archidiaconum et officialem Sandomiriensem et in Malice et Obrazów parochum, SRM secretarium, vigore commisionis inferius contentae visitatorem commissarium in anno 1718 mensibus Novembri et Decembri inchoata, ac in anno sequenti 1719 feliciter continuata, s. 47.

${ }^{15}$ Archiwum Archidiecezjalne Lubelskie (dalej AAL), AKL Rep. 60 A 105, Akta wizyty generalney w trzech dekanatach Chodelskim, Urzędowskim i Kazimierskim z woli i rozkazu [...] Kajetana Sołtyka Biskupa Krakowskiego xiążęcia Siewierskiego przez X. Antoniego Franciszka Dunina Kozickiego Kollegiaty Pilskiej Dziekana od dnia piętnastego Maja w Roku Pańskim 1781 poczętej a w roku 1782 dniach ostatnich miesiąca stycznia odprawionej i dokończonej spisane, s. 671.

${ }^{16}$ Wiśniowski, Kościół parafialny i jego funkcje społeczne, s. 212.

${ }^{17}$ AAL, AKL Rep. 60 A 105, s. 671.

${ }^{18}$ AAL, AKL Rep. 60 A 105, s. 673. 
były wykonane ze złotogłowia a pozostałe z jedwabiu ${ }^{19}$, w roku 1598 było ich dwadzieścia osiem ${ }^{20}$.

\section{Chrzcielnica}

W 1598 roku odnotowano, że w kościele jest chrzcielnica kamienna, która była dobrze zamknięta ${ }^{21}$. W kolejnej wizytacji w roku 1617 opisano ponadto, że umieszczona była na dwóch stopniach a znajdowała się w pośrodku kościoła, otoczona barierką i przykryta lnianym obrusem ${ }^{22}$. W 1689 stwierdzono, że na zewnątrz była ona pomalowana ${ }^{23}$. W następnej wizytacji w roku 1698 wspomniana kamienna chrzcielnica, stojąca w pobliżu ołtarza św. Anny, była dość stara i zniszczona tak, że wizytator ks. kanonik dr Krzysztof Dembicki zalecił aby sprawiono nową ${ }^{24}$. Wizytacja z 1718 roku zaznaczała, iż ulokowana była przed ołtarzem Trójcy Przenajświętszej. Stała ona na dwóch stopniach drewnianych, kolumna była kamienna a misa i przykrycie było drewniane, a więc była to - według zaleceń poprzedniej wizytacji - już nowa ${ }^{25}$.

\section{Paramenty}

Lustrację paramentów rozpoczynano od naczyń związanych z przechowywaniem i wystawianiem Eucharystii oraz udzielaniem Komunii św. W roku 1598 odnotowano ogólnie istnienie dwóch puszek, w tym jednej srebrnej. W kolejnej wizytacji z 1617 roku stwierdzono, że wewnątrz tabernakulum umieszczone były dwie puszki pozłocone oraz kustodia, w zakrystii zaś były jeszcze trzy puszki jedna duża srebrna i dwie małe pozłacane ${ }^{26}$. Nie we wszystkich kościołach były wówczas puszki dla przechowywania Eucharystii, dlatego zarysowany stan w Kraśniku świadczy o zamożności fabricae ecclesiae, jak też i o pietyzmie gospodarzy wobec Najświętszego Sakramentu ${ }^{27}$.

W pierwszej wizytacji radziwiłłowskiej z roku 1592 odnotowano wysoką srebrną monstrancję pozłacaną ${ }^{28}$; podczas następnej, w roku 1598, były już dwie

${ }^{19}$ AKMK, rkps AV 1, k. 35.

${ }^{20}$ AKMK, rkps AVCap 12, k. 11.

${ }^{21}$ AKMK, rkps AVCap 12, k. 11.

${ }^{22}$ AKMK, rkps AVCap 34, k. 12v.

${ }^{23}$ AKMK, rkps AVCap 55, s. 48.

${ }^{24}$ AKMK, rkps AVCap 57, Visitatio externa decanatus Urzędowiensis in archidiaconatu Zawichostensi, officialatu Sandomiriensi a. D. 1698 per R. D. Christophorum de Dambica Dembicki IUD, Cracoviensem, Sandomiriensem canonicum et officialem, praepositum Stobnicensem, SRM secretarium, de expresso consensu R. D. Joannis de Małachowice Małachowski, episcopi Cracoviensis, ducis Severiae - - in qua iura ecclesiarum, proventus parochorum una discriptionibus ecclesiarum et aedificiorum, noviter et ante extructorum, tum omnes et singuli proventus, fructus, utilitates, obventiones et emolumenta connotata fideliter et diligenter per me Albertum Carolum Mrówczyński, Cracoviensem clericum saecularem, s. 49, 51.

${ }^{25}$ AKMK, rkps AVCap 58, s. 47.

${ }^{26}$ AKMK, rkps AVCap 34, k. 12v-13.

${ }^{27}$ Wiśniowski, Kościót parafialny i jego funkcje spoteczne, s. 216-217.

${ }^{28}$ AKMK, rkps AV. 1, Wizyta w archidiakonacie zawichojskim Andrzeja z Żarnowca wikariusza kolegiaty sandomierskiej z r. 1592, z polecenia Marcina Szyszkowskiego, archidiakona zawichojskiego, kanonika krakowskiego, prepozyta iłżeckiego, k. 35. 
monstrancje: większa pozłocona i mniejsza srebrna ${ }^{29}$. W roku 1781 były dwie monstrancje srebrne pozłacane, puszek zaś cztery, dwie większe i dwie mniejsze ${ }^{30}$.

W 1592 roku wyliczono cztery krzyże: jeden duży, srebrny, pozłocony, z kamieniami w różnych kolorach, zawierające relikwie św. Andrzeja, św. Katarzyny i św. Leonarda. Kolejny krzyż był srebrny, posiadający z tyłu obrazy pasyjne i wizerunki czterech ewangelistów. Trzeci krzyż srebrny trochę mniejszy z pozłacanymi kwiatami. Czwarty niewiele różniący się od poprzedniego. W czasie wizytacji w 1598 wyliczono tylko cztery pozłacane krzyże. W roku 1617 zapisano informację o pięciu krzyżach srebrnych, w tym jedenym dużym pozłacanym. W roku 1592 były cztery srebrne pacyfikały, w 1598 wyliczono dwa pacyfikały oraz trzy srebrne. W roku 1617 odnotowano tylko dwa srebrne pacyfikały. W 1781 roku jeden krzyż srebrny z relikwiami, relikwiarz Krzyża świętego i trzy inne relikwiarze. Wówczas dokładnie podano wykaz relikwii w kościele: Drzewa Krzyża świętego otrzymane w Rzymie 15 marca 1742, a potwierdzone w konsystorzu krakowskim 13 maja 1754 roku. Relikwie świętych męczenników: św. Wiktoryna, Sekuryna, Benedykty i Modestii Anny pozyskane w Rzymie w 1764 roku, a 26 września 1765 potwierdzone zostały przez konsystorz lubelski; świętych Placydii, Kasji, Marcjalisa, Mansweta zdobyte także w Wiecznym Mieście 7 lutego 1761 roku, co poświadczył konsystorz lubelski 20 listopada 1762 roku, oraz relikwie św. Sebastiana otrzymane w Rzymie 15 stycznia 1741 roku a potwierdzone przez konsystorz krakowski razem z relikwiami Krzyża Świętego ${ }^{31}$. Wszystkie więc relikwie posiadały świadectwa autentyczności i ich kościelne potwierdzenie. W tym ostatnim inwentarzu nie pojawiły się relikwie znane z wieku XVI: św. Andrzeja, świętej Katarzyny i świętego Leonarda. Nic też nie wiadomo i ich losie.

W roku 1592 znajdowało się w zakrystii dziewięć kielichów - siedem pozłacanych a dwa srebrne. Sześć lat później kielichów srebrnych, pozłacanych było dziesięć, a srebrnych dwa. W roku 1617 informowano o dziesięciu kielichach, z których pięć było pozłacanych wewnątrz i zewnątrz, dwa jedynie wewnątrz, a pozostałe tylko częściowo. W roku 1592 odnotowano trzy pary ampułek srebrnych i jedną pozłacaną. W 1598 roku natomiast ampułek srebrnych pozłacanych było cztery, srebrne dwie i sześć z cyny. W roku 1617 wymieniono tylko trzy pary srebrnych dzbanuszków. W roku 1592 był jeden trybularz srebrny i dwa mosiężne ${ }^{32}$, a w 1598 były dwa trybularze, jeden srebrny, drugi z mosiądzu ${ }^{33}$. W roku 1617 wspomniano tylko o jednym srebrnym trybularzu.

Niezbędne do sprawowania liturgii były szaty dla celebransa i asysty. Protokół pierwsza wizytacji radziwiłłowskiej z 1592 roku informuje o niewielu szatach liturgicznych. Były wówczas dwa ornaty czerwone ze złotogłowiu i parę podob-

${ }^{29}$ AKMK, rkps AVCap 12, s. 11.

${ }^{30}$ AAL, AKL Rep. 60 A 105, s. 672.

${ }^{31}$ AAL, AKL Rep. 60 A 105, s. 671-672.

${ }^{32}$ AKMK, rkps AV. 1, k. 35.

${ }^{33}$ AKMK, rkps AVCap 65: Compendium actorum vistationis exterioris ecclesiarum existentium in et sub decanatu Pilsnensis, Mielecensi, Ropczicensis, Biecensi, Jaslensi et Żmigrodensi ad archidiaconatum Sandecensem pertinentium per. R. D. Christophorum Kazimirski, prepositum Tarnoviensem mandato Ill. et Rev. D. Georgii S.R.E. Cardinalis praesbiteris Radziwiłl nuncupati factae, k. $468 \mathrm{v}$. 
nych dalmatyk, trzeci był modry, burkatelowy ${ }^{34}$ ze złotogłowiu. Były także dwie kapy kamchowe ${ }^{35}$, jedna kapa czarna, aksamitna oraz jedna para czarnych, aksamitnych dalmatyk ${ }^{36}$. Taka skromna ilość szat liturgicznych sugeruje, iż nie przechowywano w zakrystii wszystkich posiadanych paramentów, reszta najprawdopodobniej zdeponowana była w klasztorze, a do zakrystii przynoszono jedynie niezbędne w poszczególne dni - o czym jest mowa w dokumencie powizytacyjnym z roku $1617^{37}$.

W roku 1598 w kraśnickiej zakrystii znajdowały się następujące szaty liturgiczne: trzy kapy ze złotym haftem, sześć zwyczajnych, jedwabnych; cztery ornaty ze złotem, dwadzieścia pięć pozostałych z jedwabiu; czternaście dalmatyk $\mathrm{w}$ różnych kolorach, niektóre $\mathrm{z}$ nich były ze złotem, pozostałe zaś z jedwabiu ${ }^{38}$. W roku 1617 wyliczono dwadzieścia cztery ornaty w różnych kolorach ze stułami i manipularzami, dalmatyk zaś było osiem par. Kap wszystkich było dziewięć ${ }^{39}$. W czasie wizytacji biskupa Sołtyka w 1781 roku wyliczono orantów wszystkich kolorów trzydzieści siedem, kap jedenaście, dalmatyk pięć ${ }^{40}$. Ornatów białych znajdowało się dziewiętnaście, trzy białe kapy i dwie takie dalmatyki ${ }^{41}$. Podobnie było dziewiętnaście ornatów czerwonych, dwie kapy tego koloru i dwie takie dalmatyki. Ornatów zielonych było pięć i jedna kapa w tym kolorze. Orantów w kolorze fioletowym było osiem, kapy dwie i dalmatyki. Czarnych ornatów było osiem, z tym iż pięć z nich było przeznaczonych na dni powszednie, oraz dwie kapy i dalmatyki ${ }^{42}$.

Podczas wizytacji w roku 1592 były dwadzieścia trzy obrusy. Każdy ołtarz miał być przykryty trzema obrusami - stąd ich liczba. Było tam także szesnaście korporałów, dwadzieścia szerzynek ${ }^{43}$ i trzynaście rampków. Chorągwi było sześć - trzy nowe i trzy stare - oraz pięć kociołków ${ }^{44}$. W 1598 roku w zakrystii kraśnickiej znajdowały trzydzieści trzy alby, trzydzieści pięć obrusów, dwadzieścia pięć humerałów, trzynaście lnianych welonów, dwadzieścia sznurów (cingula), dwadzieścia trzy korporały, osiem welonów na kielichy oraz welon na monstrancję. Z naczyń odnotowano jeden duży dzbanek cynowy i dwa małe, dwie miednice, jedną dużą a drugą mniejszą oraz lawaterz z cyny. Poza tym był całun jedwabny i cztery pelerynki (?) dla ministrantów, sześć chorągwi oraz dzwonki ${ }^{45}$. W roku 1781 było w kościele sześć chorągwi, pięć feretronów, krzyżów procesyjnych

\footnotetext{
${ }^{34}$ Burkatela - rodzaj ciężkiej tkaniny, przetykanej jedwabiem, brokat.

${ }^{35}$ Kamcha - bogata turecka tkanina jedwabna.

${ }^{36}$ AKMK, rkps AV. 1, k. 35.

${ }^{37}$ AKMK, rkps AVCap 34, k. 13v.

${ }^{38}$ AKMK, rkps AVCap 12, s. 11-12.

${ }^{39}$ AKMK, rkps AVCap 34, k. 13v-14.

${ }^{40}$ AAL, AKL Rep. 60 A 105, s. 677.

${ }^{41}$ AAL, AKL Rep. 60 A 105, s. 674-675.

${ }^{42}$ AAL, AKL Rep. 60 A 105, s. 675-677.

${ }^{43}$ Szerzynka - obrus ołtarzowy albo też sam szlak obrusa, obrzeżenie.

${ }^{44}$ AKMK, rkps AV. 1, k. 35.

${ }^{45}$ AKMK, rkps AVCap 12, s. 11-12.
} 
cztery, trzy pary srebrnych ampułek z tackami, srebrny trybularz z łódką, naczynia do olejów: srebrne i cynowe po jednym ${ }^{46}$.

W roku 1617 w zakrystii znajdowało się siedem świątecznych obrusów, osiem jedwabnych, dwanaście alb, osiem komeż. Korporałów było dwadzieścia trzy, dwanaście puryfikaterzy, dwadzieścia pięć ręczników, dziewięć burs. Welonów na kielichy było piętnaście. Dwie wazy cynowe na wino i dwie na wodę święconą. Na wyposażeniu zakrystii znajdowało się także urządzenie do wypieku hostii, wymienione w wizytacjach z 1592 i 1617 roku $^{47}$. W roku 1781 podano, iż ,żelaz do pieczenia opłatków" jest trzy ${ }^{48}$. W czasie tej wizytacji odnośnie bielizny ołtarzowej stwierdzono ogólnie: ,alby, obrusy, korporały, puryfikaterze, tuwalnie, ręczniki, ręczniczki tych wszystkich jest" trzysta trzydzieści sześć ${ }^{49}$.

Wizytacja w roku 1637 odbyła się 20 lutego z polecenia biskupa krakowskiego Jakuba Zadzika. Przeprowadził ją ks. Jan Karol Nerwicz, pleban w Dobrowodzie, w czasie gdy prepozytem kraśnickim był ks. Jan Malanowski († 1648). W protokole zapisano ogólnie, że w kraśnickiej zakrystii znajduje się odpowiednia ilość paramentów liturgicznych ${ }^{50}$. Pięćdziesiąt dwa lata później - w następnej wizytacji w roku 1689 - ogólnie tylko wspomniano o istnieniu w zakrystii dwóch szaf, w których przechowuje się potrzebne paramenty. W dekrecie reformacyjnym nakazano dokupić czarną chorągiew, zalecono zachować czystość w zakrystii, zwracając szczególnie uwagę na korporały, zalecono także dokupić przynajmniej dwie nowe alby ${ }^{51}$. Wizytacja z 1718 roku podobnie nie wyliczała szczegółowo żadnych paramentów liturgicznych ${ }^{52}$.

\section{Księgi liturgiczne i metrykalne}

W roku 1592 wyliczono następujące księgi: nowe Missale Romanum oraz inne dawne krakowskie mszały, z którymi przyszli zakonnicy do Kraśnika ${ }^{53}$. Była tam również nowa agenda $\mathrm{z}$ roku 1578 dla prowincji gnieźnieńskiej ${ }^{54}$, ponadto był pergaminowy graduał i takiż sam antyfonarz, oraz dwa całe psałterze, a także nowy graduał i responsoria - które nie były używane ${ }^{55}$. Należy podkreślić obecność starych ksiąg liturgicznych, np. mszałów przedsoborowych czy innych, które nie były już używane, obok nowych ksiąg, jak mszału czy agendy przygotowanej przez biskupa włocławskiego Stanisława Karnkowskiego h. Junosza (1520-1603)

${ }^{46}$ AAL, AKL Rep. 60 A 105, s. 672, 677.

${ }^{47}$ AKMK, rkps AVCap 34, k. 13v-14.

${ }^{48}$ AAL, AKL Rep. 60 A 105, s. 673.

${ }^{49}$ AAL, AKL Rep. 60 A 105, s. 677.

${ }^{50}$ AKMK, rkps AVCap 44, Acta vistationum decanatum: Urzędowiensis, Zawichostensis et Opatoviensis ad archidiaconatum Zawichostensem pertinentium, authoritate R. D. Jacobi Zadzik, episcopi Cracoviensis a. D. 1637 peracta, s. 33.

${ }^{51}$ AKMK, rkps AVCap 55, s. 48, 52.

${ }_{52}^{52}$ AKMK, rkps AVCap 58, s. 48.

${ }^{53}$ C. Krakowiak, Mszat z Kraśnika, w: Encyklopedia Katolicka, t. 13, kol. 463.

${ }^{54} \mathrm{~S}$. Karnkowski, Agendorum ecclesiasticorum liber, in usum provinciae Gnesnensis conscriptus, apud Maternum Cholinum, Coloniae 1578.

${ }^{55}$ Wydanie tychże dzieł nie jest możliwe do identyfikacji. 
zaraz po synodzie piotrkowskim z 1577 roku, na którym kościół polski przyjął dekrety Soboru Trydenckiego. Przypomnieć należy także, iż nie we wszystkich ówczesnych parafiach one się znajdowały - w niedalekiej Słupi nie było obowiązującego mszału rzymskiego a jedynie przedsoborowy, ani też nowej agendy, tylko ze starego antyfonarza kilka kart ${ }^{56}$. Wizytator wówczas na koniec skonstatował, że żadnych ksiąg heretyckich u zakonników nie znalazł ${ }^{57}$. W roku 1617 było w zakrystii już osiem mszałów, dwie agendy, graduale, antyfonarz i nowy psałterz ${ }^{58}$. W czasie wizytacji w roku 1637 ogólnie stwierdzono, że w zakrystii znajduje się odpowiednia ilość ksiąg do śpiewu, mszałów zaś było wówczas dziewięć - czyli tyle ilu było kapłanów w klasztorze. Wtenczas także wspomniano, iż ówczesny prepozyt zaopatrzył bibliotekę w konieczne księgi liturgiczne, bez szczegółowego ich jednak wymienienia ${ }^{59}$.W roku 1719 z kolei stwierdzono ogólnie, że księgi liturgiczne (mszały, agendy i księgi chórowe) znajdują się w dobrym stanie i porządku $^{60}$. W roku 1781 podano, iż „mszałów, agend, agendek” było osiemnaście, a trzy mszały posiadały srebrne narożniki ${ }^{61}$.

W wizytacjach przeprowadzonych w latach 1592 i 1598 ogólnie wspomniano, że prowadzone są $\mathrm{w}$ Kraśniku księgi metrykalne ochrzczonych i zaślubionych. W roku 1617 zaznaczono, że zaczęto je pisać w roku „169”. Pisarz opuścił zatem w zapisie daty jakąś cyfrę, istotne jest pytanie, w którym miejscu popełnił błąd: czy pominął ,5" pomiędzy cyframi 1 i 6 czy ,0" pomiędzy cyframi 6 i $9^{62}$. Brak „5”, oznaczałby rok 1569, co świadczyłby o bardzo szybkim wprowadzeniu tego soborowego zalecenia w Kraśniku, jednym z najwcześniejszych w Polsce. W diecezji krakowskiej wprowadzono je zarządzeniem biskupa Piotra Myszkowskiego h. Jastrzębiec (1510-1591) z roku 1578; ogólnie w Polsce zobowiązał do tego plebanów synod prowincjalny z roku 1589, a szczególnie czyniła to „Pastoralna” Maciejowskiego ${ }^{63}$. Pominięcie „0", jako trzeciej cyfry, oznaczałoby, że chodzi o rok 1609, co wskazywałby bardziej na czas rozpoczęcia kolejnego tomu ksiąg. W roku 1718 zapisano, że oprócz wspomnianych ksiąg metrykalnych prowadzono jeszcze księgi zmarłych i przystępujących do wielkanocnej Komunii świętej ${ }^{64}$. W roku 1781 natomiast szczegółowo opisano stan parafialnych ksiąg metrykalnych. Księgi ochrzczonych rozpoczynają się w roku 1629 i doprowadzone są do roku 1670, po którym brakuje sześćdziesięciu lat (1671-1731). Od roku 1732 jest prowadzona bez przerwy do 1781 . Metryki zaś ślubów i zmarłych zaczynają się

\footnotetext{
${ }^{56}$ AKMK, rkps AV. 1, k. 23v.

${ }^{57}$ AKMK, rkps AV 1, k. 35.

${ }^{58}$ AKMK, rkps AVCap 34, k. 14; Tamże AV 1, k. 35v.

${ }^{59}$ AKMK, rkps AVCap 44, s. 33.

${ }^{60}$ AKMK, rkps AVCap 58, s. 48.

${ }^{61}$ AAL, AKL Rep. 60 A 105, s. 677.

${ }^{62}$ AKMK, rkps AVCap 34, k. 14; Tamże AV 1, k. 35v.

${ }^{63}$ Nasiorowski, ,List Pasterski”, s. 212; C. Kuklo, Staropolska rejestracja metrykalna ślubów, chrztów i pogrzebów w warsztacie badawczym historyka, w: Człowiek w teatrze świata. Studia o historii i kulturze dedykowane profesorowi Stanisławowi Grzybowskiemu z okazji osiemdziesiatych urodzin, red. B. Popiołek, Kraków 2010, s. 38-40.

${ }^{64}$ AKMK, rkps AVCap 58, s. 48.
} 
dopiero od roku 1747 i są powadzone systematycznie do $1781^{65}$. Tak więc pod koniec wieku XVIII były już spore braki w kraśnickich księgach metrykalnych.

\section{Podsumowanie}

Z przedstawionego w czasie wizytacji obrazu wyposażenia świątyni kraśnickiej, możemy stwierdzić, iż kościół ten, zachowując przepisy prawa kościelnego, był dobrze wyposażony w niezbędne do należytego sprawowania liturgii paramenty. Z opisów wizytacyjnych sądzić można, iż niektóre z prezentowanych elementów występowały w większej liczbie aniżeli podano, a w innych wypadkach podano tylko ogólnie, iż była tam odpowiednia, wystarczająca liczba niektórych paramentów - ten sposób opisu także był spotykany w innych protokołach powizytacyjnych $^{66}$. Dość wcześnie zaopatrywano się w nowe wymagane prawem kościelnym księgi czy paramenty, świadczy to o wierności przepisom Kościoła przez kanoników regularnych. Zapewne zdecydowana większość z nich była sprawiona była przez miejscowych proboszczów, będących zarazem przełożonymi wspólnoty kanonickiej ${ }^{67}$.

Zgromadzone w okresie staropolskim w kościele i zakrystii kraśnickiego Kościoła sprzęty i paramenty były często wspaniałymi dziełami rzemiosła artystycznego, dlatego oprócz swej podstawowej funkcji liturgicznej były także czynnikiem kulturotwórczym. Najbardziej będąc narażone na zniszczenie dzieliły w pełni los kościoła, parafii i zakonu, stąd niewielka liczba zachowanego dawnego wyposażenia kościoła.

słowa kluczowe: wizytacja biskupia; staropolskie wizytacje; paramenty liturgiczne; Kraśnik

\section{BIBLIOGRAFIA}

\section{Źródla}

Archiwum Archidiecezji Lubelskiej, sygn. AKL Rep. 60 A 105.

Archiwum Kurii Metropolitalnej w Krakowie sygn.: AV. 1; AVCap 12; AVCap 34; AVCap 55; AVCap 44; AVCap 57; AVCap 58.

Dokumenty Soborów Powszechnych, oprac. A. Baron, H. Pietras, t. 4, Kraków 2004.

\section{Opracowania}

Czajkowski J. A., Opis kościoła parafialnego w Kraśniku i wiadomość historyczna o kanonikach regularnych lateraneńskich, „Pamiętnik Religijno-Moralny”, 8 (1845) z. 1, s. 34-49;

Katalog zabytków sztuki w Polsce, t. 8: Województwo lubelskie, red. R Brykowski, E. Smulikowska, Z. Winiarz, z. 9: Powiat kraśnicki, oprac. J. Galicka, E. Smulikowska, Warszawa 1961.

\footnotetext{
${ }^{65}$ AAL, AKL Rep. 60 A 105, s. 678.

${ }^{66}$ Wiśniowski, Kościół parafialny i jego funkcje społeczne, s. 220.

${ }^{67}$ Czajkowski, Opis kościoła parafialnego w Kraśniku, s. 41.
} 
Korpysz E., Zmiany w sposobie przechowywania Eucharystii w świetle działalności bp. Mattea Gibertiego oraz potrydenckich reform św. Karola Boromeusza i późniejszych synodów, w: Studia de Arte Moderna, t. 1: Sztuka po Trydencie, red. K. Kuczmana, A. Witko, Kraków 2014, s. 47-53.

Kuklo C., Staropolska rejestracja metrykalna ślubów, chrztów i pogrzebów w warsztacie badawczym historyka, w: Człowiek w teatrze świata. Studia o historii i kulturze dedykowane profesorowi Stanisławowi Grzybowskiemu z okazji osiemdziesiatych urodzin, red. B. Popiołek, Kraków 2010, s. 38-40.

Nasiorowski S., „List Pasterski” kard. Bernarda Maciejowskiego, Lublin 1992; Rafałko A., Dzieje tabernakulum w Polsce, w: Studia z dziejów liturgii w Polsce, red. W. Schenk, t. 4, Lublin 1984.

Sobieszczański F. M., Wiadomości historyczne o sztukach pięknych w dawnej Polsce zawierające opis dziejów i zabytków budownictwa, rzeźby, snycerstwa, malarstwa i rytownictwa, z krótka wzmianka o życiu i dziełach znakomitszych artystów krajowych, lub w Polsce zamieszkatych, t. 1, Warszawa 1847.

Szymanek W., Z dziejów powiatu janowskiego i kraśnickiego w latach 1474-1975, Lublin 2003.

Weryński H., Tabernakulum. Szkic historyczno-liturgiczny, Miejsce Piastowe 1932.

Wiśniowski E., Kościót parafialny i jego funkcje społeczne w średniowiecznej Polsce, „Studia Theologica Varsaviensa”, 7 (1969) nr 2, s. 187-238.

\title{
THE LITURGICAL EQUIPMENT OF THE MONASTIC CHURCH IN KRAŚNIK, ACCORDING TO THE CRACOW EPISCOPAL VISITATION RECORDS OF THE OLD POLISH PERIOD
}

\begin{abstract}
Summary
The church in Kraśnik, as presented in the visitation records, was well equipped with the necessary paraments to perform the liturgy. It is also noteworthy that all the church regulations were obeyed. From the description of the visitation, it can be concluded that some of the presented elements were more numerous than it was noted, and in other cases, it was only generally stated that there was a sufficient number of some paraments - this style of description was also typical of other visitation reports. The Canons Regular quite early equipped themselves with church's new books and paraments, as the Church's law required; it proves that Canons Regular met the Church's regulations. The vast majority of books and paraments were acquired by local parish priests, who were also superiors of the Canons community.

Paraments and other equipment collected in the Kraśnik church and its sacristy in the Old Polish period were often excellent works of artistic craftsmanship, and therefore, in addition to their basic liturgical function, they had also cultural importance. Being most susceptible to destruction, they shared the fate of the church, the parish and the religious order, hence a small number of the old preserved church equipment.
\end{abstract}

Keywords: an episcopal visitation; visitations in the Old Polish period; liturgical paraments; Kraśnik 